\title{
Analysis of The Factors That Influence The Visit Intensity of Brastagi Tourism, Karo Provinsi District, Sumatera Utara
}

\author{
Shadifah \\ Faculty of Economics, \\ Universitas Negeri Medan, Indonesia \\ Dr. Zahari Zen, M.Sc \\ Faculty of Economics, \\ Universitas Negeri Medan, Indonesia \\ Muhammad Fitri Rahmadana \\ Faculty of Economics, \\ Universitas Negeri Medan, Indonesia
}

\begin{abstract}
This study aims to determine and analyze factors such as tourist income, facilities, and infrastructure, the number of tourist family members and the distance traveled by tourists that affect the intensity of tourist visits to Brastagi. The population of this study was tourist visitors in the District of Brastagi, Karo Regency, with random cluster sampling. After calculating using Slovin formula, it was decided that the number of samples to be taken was 90 people. The data used in this study are primary data through questionnaires distributed to samples and interviews to complete data, observation, and documentation as well as secondary data which includes data from the Karo District Tourism Office and other sources relevant to the purpose of this study. The model used in this study is the basic model of demand as stated by Sukirno (2002), where several variables are assumed to be fixed, and several other variables are added to the model. The estimation of tourist visit intensity, tourist income-free variable, facilities and infrastructure has a positive and significant effect on the intensity of tourist visits to Brastagi, while the Mileage variable has a negative and insignificant effect on intensity of tourist visits to Brastagi at $\alpha=5 \%$.
\end{abstract}

Keyword : Tourism, Brastagi, visit intensity

\section{INTRODUCTION}

Karo Regency is one of the tourist destinations in North Sumatra Province. In 2015, the number of tourists coming to Karo District reached 501,048 people consisting of 54,109 foreign tourists and 446,939 domestic tourists. Whereas in 2016 it increased by $8.01 \%$ to 541,219 people consisting of 52,346 foreign tourists and 488,883 domestic tourists.

One of the tourist destinations in the very famous Karo Regency is Brastagi. Every holiday season, Brastagi becomes the most targeted tourist destination. Not only by the people of Medan but also other areas in North Sumatra. Hundreds of thousands of visitors come to the city, which is only about 66 kilometers $(\mathrm{km})$ from Medan. Based on the data from the Pemkab Karo Tourism Office, until the end of 2017, the number of visitors to various tourist attractions in the area reached 550,223 people. This number increased compared to the previous year which recorded 541,219 people. 
Brastagi is located at an altitude of around 4,594 feet above sea level (asl) and is surrounded by rows of mountains, having fresh air with beautiful, vast and green expanses of agriculture. This situation makes this city the leading tourist destination of Medan, especially before the New Year and holidays. The comparative advantage of tourism in Karo Regency compared to other regions in North Sumatra is the strategic position of the City of Brastagi and can be used as a gateway for tourism trips to other regions such as Parapat, Bahorok, and Silalahi.

Accommodation facilities to the area are also very adequate, have a beautiful and serene nature, as well as a unique and unique cultural appeal. Besides, the typical agricultural products as an attraction for agro-tourism are also an exceptional value for this region. This area has much natural uniqueness such as natural hot spring (lau debuk-debuk), waterfall (sipisopiso), volcano (sibayak and sinabung), hill (gundaling), cave, lake and others. however, of all these attractions, the gundaling hill is the most visited, especially during holidays.

Gundaling Hill is located in the middle of Brastagi and is only $3 \mathrm{~km}$ from the City of Brastagi, to reach the hill, can be done on foot or using a 'Sado' (horse-drawn carriage), a typical vehicle drawn by a horse. This hill offers the beauty of the garden, which is suitable for relaxing and exercising. The still active panorama of the volcano with its unusual volcanic activity can also be enjoyed from the top of Gundaling Hill. Brastagi also has an attraction from the side of its traditional buildings such as traditional houses, completing Brastagi to become more intact as well as cultural tourism. As a tourist city, Brastagi also pampers its visitors by providing various facilities. Complete hospitality facilities here. Starred hotels with varied prices offer designs that on average show local cultural characteristics. Tourism in Tanah Karo, especially Brastagi tourist destination, in addition to the potential that has not been fully utilized is also critical to consider what factors cause people to visit these tourist destinations, also what factors cause reluctant people to visit tourist areas in Brastagi.

Following the phenomenom, this study aims to determine and analyze factors such as tourist income, facilities, and infrastructure, the number of tourist family members and the distance traveled by tourists that affect the intensity of tourist visits to Brastagi.

\section{Tourism}

\section{LITERATURE REVIEW}

In essence, tourism is a process of traveling temporarily from someone or more to another place outside his residence. The drive for their departure was due to various interests, both because of economic, social, cultural, political, religious, health and other interests such as merely being curious, adding to experience or learning (Suwantoro, 1997). In the development of tourism, in general, there also appears the term sustainable tourism. According to (Swarbrooke, 1998) in (Utami, 2006), said that in essence, sustainable tourism must be integrated into three dimensions. These three dimensions are, (1) environmental dimensions, (2) economic dimensions, and (3) social dimensions. Furthermore, based on the context of sustainable development, sustainable tourism can be defined as tourism development that is by the needs of tourists while paying attention to sustainability (conservation, environmental dimension), providing opportunities for the younger generation to use economic dimension and develop it based on social dimension existing ones.

\section{Tourism Demand}

The demand theory explains the relationship between various combinations of prices and the number of items that consumers want and can buy at various price levels for a given period. According to (McEachem, 2000), the market demand for a resource is the sum of all requests for various combinations of uses of these resources. According to (Yoety, 2008) there are three 
consumer behaviors in meeting the needs of goods and services: 1) limited income, 2) Making purchases by acting rationally, and 3) wanting to achieve satisfaction (to maximize their total satisfaction).

Tourism demand affects all economic sectors: individuals, small and medium enterprises, private companies, and the government sector (Stabler, Papatheodorou, \& Sinclair, 2009). Tourism demand is also based on its budget, and this is the key to tourism demand. Someone will consider reducing their budget for a vacation interest. Meanwhile, this holiday activity is an activity that can create demand because tourism activities carried out by tourists by themselves will require services, such as accommodation, catering, restaurants, entertainment, and other services. The visual diagram about tourism consumption can be seen in Figure 1.

Figure 1. Tourism consumption

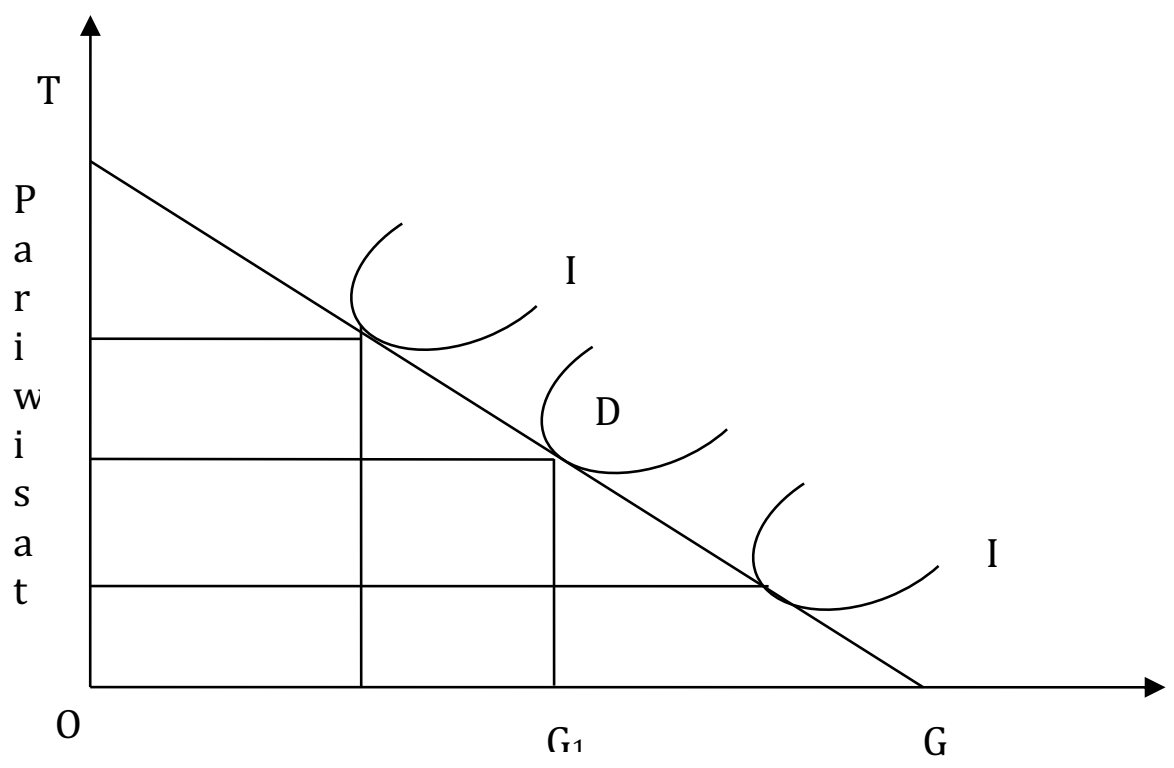

METHODOLOGY

The population of this study was tourist visitors in the District of Brastagi, Karo Regency, with random cluster sampling. After calculating using Slovin formula, it was decided that the number of samples to be taken was 90 people. The data used in this study are primary data through questionnaires distributed to samples and interviews to complete data, observation, and documentation as well as secondary data which includes data from the Karo District Tourism Office and other sources relevant to the purpose of this study.

The model used in this study is the basic model of demand as stated by Sukirno (2002), where several variables are assumed to be fixed, and several other variables are added to the model to form the following equation ;

$$
I K W=f(P W, S P, J A K, J T)
$$

While the elasticity of the tourism demand model of the city of Brastagi is as follows;

$$
\begin{aligned}
& \operatorname{LogIKW}=\beta 0+\beta 1 \mathrm{PW}+\beta 2 \mathrm{SP}+\beta 3 \mathrm{JAK}+\beta 4 \mathrm{JT}+\mathrm{e} \\
& \operatorname{LogIKW}=\beta 0+\beta 1 \log \mathrm{PW}+\beta 2 \operatorname{LogSP}+\beta 3 \operatorname{LogJAK}+\beta 4 \operatorname{LogJT}+\mathrm{e}
\end{aligned}
$$


dimana:

IKW $=$ The intensity of tourist visits (how many times).

$\mathrm{PW}=$ Tourist income (in rupiahs).

$\mathrm{SP}=$ Facilities and infrastructure (how many).

$\mathrm{JAK}=$ Number of family members (people).

$\mathrm{JT}=$ Distance $(\mathrm{KM})$

$\mathrm{e}=$ Error term

$\beta 0=$ Constanta

$\beta 1, \beta 2, \beta 3, \beta 4=$ The variable coefficient that explains the elasticity of the independent variable

\section{Intensity of Tourism Visits to Brastagi}

\section{RESULT}

Table 1 shows the intensity of visitors to visit Brastagi attractions in one year, whether just relaxing or wanting to enjoy the rides that have been provided on tourist attractions.

Table 1. Classification Based on Visit Intensity

\begin{tabular}{|c|c|c|c|}
\hline \multirow{2}{*}{ No } & \multirow{2}{*}{ Visit intensity } & \multicolumn{2}{|c|}{ Response } \\
\cline { 3 - 4 } & & Frequency (people) & Percentage \\
\hline 1 & $1-2$ & 22 & 22 \\
\hline 2 & $3-4$ & 32 & 32 \\
\hline 3 & $5-6$ & 25 & 25 \\
\hline 4 & $\geq 7$ & 21 & 21 \\
\hline
\end{tabular}

\section{Tourist Income}

The income referred to in this study is the total income or total pocket money received by respondents each month. A complete classification of tourist income can be seen in table 2 .

Table 2. Classification Based on Income per month

\begin{tabular}{|c|l|c|c|}
\hline \multirow{2}{*}{ No } & Amount of money & \multicolumn{2}{|c|}{ Response } \\
\cline { 3 - 4 } & & Frequency & Percentage \\
\hline 1 & Less than $\operatorname{Rp~} 1,000,000$ & 7 & 7 \\
\hline 2 & Rp 1,000,000 - Rp 2,000,000 & 38 & 38 \\
\hline 3 & Rp 2,000,000 - Rp 3,000,000 & 26 & 26 \\
\hline 4 & More than $\operatorname{Rp~3,000,000~}$ & 29 & 29 \\
\hline
\end{tabular}

\section{Supporting Facilities and Infrastructure}

The facilities and infrastructure in this study are all facilities in the tourist area of Brastagi. Complete information about supporting facilities and infrastructure can be seen in table 3 .

Table 3. Classification Based on Facilities and Infrastructure

\begin{tabular}{|c|l|c|c|}
\hline \multirow{2}{*}{ No } & \multirow{2}{*}{ Facility } & \multicolumn{2}{|c|}{ Response } \\
\cline { 3 - 4 } & & Frequency & Percentage \\
\hline 1 & 0 (None) & 20 & 20 \\
\hline 2 & 1 (a little) & 20 & 20 \\
\hline 3 & 2 (incomplete) & 20 & 20 \\
\hline 4 & 3 (Complete) & 20 & 20 \\
\hline 5 & 4 (Very Complete) & 20 & 20 \\
\hline
\end{tabular}




\section{Number of Family Members}

In this study, a classification of samples taken was also carried out. Information about the total number of family members in a complete sample can be seen in table 4 .

Table 4 Classification Based on Number of Family Members

\begin{tabular}{|c|l|c|c|}
\hline No & Number of family members & Frequency & Percentage \\
\hline 1 & 1 person & 48 & 48 \\
\hline 2 & 2 persons & 23 & 23 \\
\hline 3 & 3 people & 15 & 15 \\
\hline 4 & 4 people & 11 & 11 \\
\hline 5 & Above 4 people & 3 & 3 \\
\hline
\end{tabular}

Sumber: data primer diolah

\section{Distance}

Distance is the range that the respondent must travel to reach the destination, where the distance from the house to the tourist attraction can influence someone to visit a tourist attraction. The classification of samples based on distance can be seen in table 5 .

Table 5. Classification of Respondents by Distance

\begin{tabular}{|c|l|c|c|}
\hline \multirow{2}{*}{ No } & \multicolumn{2}{|c|}{ Distance } & \multicolumn{2}{|c|}{ Response } \\
\cline { 3 - 4 } & & Frequency & Frequency \\
\hline 1 & $0-15 \mathrm{~km}$ & 31 & 31 \\
\hline 2 & $16-30 \mathrm{~km}$ & 30 & 30 \\
\hline 3 & $31-45 \mathrm{~km}$ & 24 & 24 \\
\hline 4 & $>45 \mathrm{~km}$ & 15 & 15 \\
\hline
\end{tabular}

\section{Results of Research Estimates}

Statistical analysis was used to see the validation and models used in this study. Statistical tests were performed on the regression model results. The regression estimation results for the intensity model of tourist visits are as follows:

Table 6. Results of Estimated Number of Tourist Models

Dependent Variable: LOG(IKW)

Method: Least Squares

Date: 12/27/18 Time: 19:35

Sample: 190

Included observations: 78

\begin{tabular}{crrrr}
\hline \hline \multicolumn{1}{c}{ Variable } & Coefficient & Std. Error & t-Statistic & Prob. \\
\hline \hline C & 1.536648 & 0.221735 & 6.930098 & 0.0000 \\
LOG(PW) & 0.060251 & 0.035539 & 1.695344 & 0.0943 \\
LOG(SP) & 0.245484 & 0.128895 & 1.904529 & 0.0608 \\
LOG(JAK) & -0.418471 & 0.119628 & -3.498091 & 0.0008 \\
LOG(JT) & -0.020884 & 0.053342 & -0.391516 & 0.6966 \\
\hline \hline R-squared & 0.181606 & Mean dependent var & 1.496258 \\
Adjusted R-squared & 0.136763 & S.D. dependent var & 0.605000 \\
S.E. of regression & 0.562109 & Akaike info criterion & 1.747713 \\
Sum squared resid & 23.06554 & Schwarz criterion & 1.898784 \\
Log likelihood & -63.16080 & Hannan-Quinn criter. & 1.808189 \\
F-statistic & 4.049777 & Durbin-Watson stat & 2.087676 \\
Prob(F-statistic) & 0.005077 & & \\
\hline \hline
\end{tabular}


The results of the above analysis can be written in linear equations as follows:

$\operatorname{LogIKW}=1.536648+0.060251^{*} \log \mathrm{PW}+0.245484^{*} \operatorname{LogSP}-0.418471^{*} \operatorname{LogJAK}-0.020884^{*}$ LogJT

The estimation of tourist visit intensity (IKW), tourist income-free variable (PW), facilities and infrastructure (SP) has a positive and significant effect on the intensity of tourist visits (IKW) to Brastagi, while the Mileage variable (JT) has a negative and insignificant effect on intensity of tourist visits (IKW) to Brastagi at $\alpha=5 \%$.

\section{CONCLUSIONS}

Based on the results stated, the conclusions of this study are as follows: Tourist expenditure has a positive and significant effect on the intensity of tourist visits to Brastagi. This condition is because every tourist takes into account the costs they will incur during visiting a tourist attraction, for local tourists who choose to visit Brastagi attractions because the costs incurred are cheaper. Although not all tourists take into account the costs, some tourists come to visit on the grounds of wanting to enjoy the beauty of Brastagi attractions, so that tourists are not concerned with the travel costs they will incur. Besides, facilities and infrastructure have a positive and significant effect on the intensity of tourist visits to Brastagi. This is because facilities are needed to support the industrial value of a tourist attraction, if the facilities at a tourist attraction are inadequate, it can affect the willingness of tourists to travel. Although a tourist attraction has the potential, it has natural beauty but does not have adequate facilities, and it will undermine the intention of tourists to visit. Brastagi has complete facilities, which causes tourists to visit Brastagi. Not only that, the number of family members has a positive and significant effect on the intensity of tourist visits. Moreover, finally, the distance traveled negatively and not significantly on the intensity of tourist visits to Brastagi. This is since the field shows that distance is not an obstacle for tourists to travel and Brastagi is designed not only as a mountain tourist spot but also as a culinary tourist spot, playground, and cultural tourism

\section{References}

McEachem, W. A. (2000). Ekonomi Makro: Pendekatan Kontemporer, terj. Sigit T (Salemba Em). Jakarta.

Stabler, M. J., Papatheodorou, A., \& Sinclair, M. . (2009). The economics of tourism. Routledge.

Sukirno, S. (2002). Teori Mikro Ekonomi (Cetakan Ke). Jakarta: PT Raja Grafindo Persada.

Suwantoro, G. (1997). Dasar-Dasar Pariwisata. Yogyakarta: Andi.

Swarbrooke, J. (1998). Sustainable Tourism Management. New York: Cabi.

Utami. (2006). Konsep Pariwisata (Kajian Sosiologi dan Ekonomi).

Yoety, O. A. (2008). Ekonomi Pariwisata: introduksi, informasi, dan aplikasi. Penerbit Buku Kompas. 